\title{
Meaningful Intersections of Social Justice and Contemporary Cultural Competencies in a New Zealand Master's level Initial Teacher Education \\ Programme
}

Steven Sexton

University of Otago, New Zealand

\begin{abstract}
In New Zealand, it is illegal to discriminate based on a person's gender, race, ability or sexual orientation; however, this is not always the experience of student teachers. To promote, support and facilitate student teachers learning to be effective classroom practitioners, this paper's initial teacher education programme was designed to support student teachers in developing critical reflexivity of their own developing self-as-teacher role identity. Specifically, this paper presents three life stories of how master's level student teachers were supported by the intersections of social justice and New Zealand's unique biculturalism. Student teachers challenged an educational community's, a school's or a teacher's normative attitudes, values, and beliefs regarding gender, race, ability and sexual orientation of these student teachers. These life stories highlight the importance of the educational setting's impact on the social construction of identity of not only the students in the school setting but also the wider school community.
\end{abstract}

Keywords: social justice; initial teacher education; cultural competencies; identity; life story

Published Date: November 2017

Published Online: $25^{\text {th }}$ November

2017

Corresponding Author: Steven Sexton, University of Otago, New Zealand, steven.sexton@otago.ac,nz

\section{Introduction}

In New Zealand it is illegal to discriminate based on a person's gender, religion, ethnicity, disability, age, politics, ethnicity, sexual orientation as well as a person's employment, family and marital status ${ }^{[1]}$. Issues arise because like many societies, New Zealand is multicultural with over 200 ethnicities recorded in the last census ${ }^{[2]}$. While the numeric majority are Pākehā/European (Pākehā is a Māori term referring to non-Indigenous New Zealanders of European descent), there is a significant Māori (Indigenous New Zealanders) population with legally recognised customs and traditions. As a result, the New Zealand educational system explicitly incorporates biculturalism as one of its principles that guides how schools plan, prioritise, and implement the curriculum ${ }^{[3]}$. This explicit inclusion of biculturalism is also reflected in this paper's initial teacher education (ITE) programme as it demonstrates, models and promotes New Zealand's unique cultural competencies ${ }^{[4]}$.

The 1989 Education Act guarantees education that is free and compulsory from the age of six to sixteen and is available to students from the age of five to nineteen ${ }^{[5]}$. Consequently, the institution of schooling has a significant role in the social construction of identity on both those who are required by law to be in it and those who choose to be in it.

This study's ITE programme's conceptual framework positions social justice as the, "respect for differences between groups and between individuals and the dialectical overcoming of conditions of oppression and inequality" ${ }^{[6]}$ (p. 163). Specifically, 
social justice challenges the forms of oppression that derive from harmful social, political and/or cultural beliefs about a student teacher's gender, race, ability and sexual orientation ${ }^{[7-8]}$. This study's meaningful intersections of social justice and contemporary cultural competencies promote, support and facilitate the self-as-teacher development of ITE student teachers.

Promoting, supporting and facilitating self-as-teacher identity of student teachers may require ITE programmes to challenge schools', teachers' or educational communities' normative attitudes, values and beliefs regarding gender, race, ability and sexual orientation ${ }^{[9-10]}$. Students want good teachers and are able to tell you what makes a good teacher for them. Both international and domestic research studies have noted that students assess their teachers according to the quality of their teaching, not by their biological classification ${ }^{[8,11-12]}$. Therefore, ITE programmes should promote, facilitate and scaffold student teachers as they learn and practice how to be effective teachers not any other adjectiveleading teachers.

This study concerns student teachers in a Master of Teaching and Learning (MTchgLn) ITE programme. In their first session as student teachers, the students are welcomed with a Mihi Whakatau (Māori welcome) in te reo Māori (the indigenous language of New Zealand). Then they are guided through how to craft their own mihimihi (a Māori introduction that includes where they are from, who they are related to and who they are) which the student teachers present to their cohort on their second day of study. This crafting and presentation of their mihimihi puts into practice a well-known whakatauki, He aha te mea nui o te ao? He tangata! He tangata! He tangata! Whakatauki are a poetic form of the Māori language merging historical events or holistic perspectives with underlying messages and are still meaningful in Māori society. This whakataukī asks the question 'What is the most important thing in the world?' then answers, 'It is people! It is people! It is people!' Starting the year with students introducing themselves celebrates who they are and where they are from to begin building the relationships necessary for their journey in becoming teachers. As stated, the Ministry of Education and this ITE programme explicitly support New Zealand's unique biculturalism and as such promotes the development of student teachers' own cultural competencies.

\section{Programme Design and Student Teachers' Self-as- Teacher Development}

This MTchgLn programme is built upon three pillars of realistic teacher education ${ }^{[13]}$, critical reflexivity ${ }^{[14-}$ 15] and adaptive expertise ${ }^{[16]}$. These three pillars are not linear, sequential or cyclic but work together to support the development of the student teachers. Realistic teacher education requires student teachers to build upon their prior experiences as students in the classroom as they process the, "needs, concerns, values, meanings, preferences, feeling, and behavioural tendencies" ${ }^{\prime 13]}$ (p. 42) or gestalts in their learning to take on the role of the classroom teacher. Korthagen et al. ${ }^{[13]}$ noted that experience is a starting point for learning; however, for gestalts student teachers need sufficient practical experiences. These practical experiences need to support the relationship between theoretical and practical components of ITE.

While Schön ${ }^{[17]}$ laid the foundation for reflective practice that focused on reflection-in action and reflection-on-action, Thompson and Pascal ${ }^{[15]}$ took Schön's work further to include reflection-forpractice. Thompson and Pascal ${ }^{[15]}$ defined their differences between reflexive and reflective practice noting that reflexivity is key to critically reflective practice. This MTchgLn programme takes the position that student teachers need critical reflexivity combining Cunliffe's[14] critical reflexivity with Thompson and Pascal's ${ }^{[15]}$ reflection-in/-on/-for action. This MTchgLn programme's critical reflexivity requires student teachers to go beyond reflection and explicitly include possibilities for self-as-teacher development in how they see both teaching and themselves as the teacher.

Over the course of this one-year programme, the student teachers take on more and more of the dayto-day responsibilities of their mentor teachers. Student teachers spend half the year in one school 
before transferring to a second school to experience a different educational setting. These teaching experiences are designed with the intent that the student teachers would put into everyday practice their initial forays into becoming adaptive experts ${ }^{[16]}$. Adaptive experts are, "driven by the moral imperative to promote the engagement, learning, and well-being of each of their students"[16] (p. 5). It was anticipated that the structured experiences both within the University and partner schools would support these student teachers in developing critical reflexivity of own adaptive practice as a central tenet of their future self-regulated learning as teachers.

Research has previously reported how this programme has positively challenged student teachers' naïve preconceptions of teaching and being the teacher and how these student teachers were learning to think, know, feel and act like a teacher ${ }^{[18-19]}$. Sexton ${ }^{[18]}$ highlighted examples of how primary and secondary student teachers' selfefficacy has been influenced by their programme while Sexton \& Williamson-Leadley ${ }^{[19]}$ investigated the advantages of video capturing of teaching practice on primary student teachers adaptive expertise. Therefore, this programme anticipated that the MTchgLn student teachers' sense of self-asteacher would be challenged by the realities of classroom experience.

\section{Methodology}

As this article focusses on promoting, supporting and facilitating the self-as-teacher development role identity of student teachers, the qualitative methodology of life stories was used. Life stories offer an interpretive framework through which the meaning of human experience is revealed in personal accounts ${ }^{[20-22]}$. This qualitative approach allows for the documentation of the inner experiences of individuals, such as how they subjectively interpret, understand and define critical episodes of their life ${ }^{[23-24]}$. More importantly for the present study, the stories were a way of avoiding the excessive imposition of external theories and constructs of the researcher on the student teachers so as not to stifle the story-telling urge ${ }^{[25]}$.
Student teachers' memories are not explicit and literal disclosures of their past as people reconstruct past events in light of knowledge about the outcomes of their lives ${ }^{[26]}$. This very reconstruction can be more telling even though some people might unconsciously assimilate events of the past, adjust perceptions or simply try to make sense of their present by distorting the event. Each person is a historian of their own self creating an internally consistent representation of their own life so that their past, present and future appear to be congruent ${ }^{[26]}$. Therefore, recollection is facilitating rather than displacing objectivity of recall because it provides a more comprehensive perspective ${ }^{[27]}$.

This present study's interpersonal context highlights then explores the powerful influences that have shaped these student teachers ${ }^{[24]}$. The story is interactive as human behaviour is shaped and formed as the result of a meaningful interaction with the social and cultural environment and all its participants, specific to this present study: schooling and mentor teacher experiences. Life story is dynamic as it allows the respondents to re-examine and reconstruct their own perceptions of personal experiences $^{[20-21,24,27]}$.

As it has been shown, life stories are the study of the ways in which humans experience the world. They also show the extent to which humanness is learned, and how once learned, can be used expressively to shape and change one's understanding of the world. Teacher candidates in telling their story establish a verisimilitude through the coherence of meanings. This narrative despite confusions, ambiguities and contradictions enable consistency of interpretation in meaning.

\subsection{Participants}

In the last New Zealand teacher census in $2015^{[28]}$ almost $73 \%$ of teachers were Pākehā/European with just under 10\% Māori and 3\% Pasifika, plus other nationalities. In the wider New Zealand population, the 2013 Census $^{[2]}$ reported $74 \%$ of the population identified as Pākehā/European, $15 \%$ as Māori and $7 \%$ as Pasifika with other nationalities making up the rest. Therefore, while the teaching population 
reflects the wider population in terms of Pākehā/European it underrepresents the Māori and Pasifika populations. The demographics of this MTchgLn programme follows a similar trend of greater representation of $P \bar{a} k e h \bar{a} /$ European student teachers than other nationalities. Since 2014, one hundred and eighty four students have completed this programme and gained teacher registration. Of these, 17 (9.2\%) self-identify as Māori and five as Pasifika (2.7\%) with 158 Pākehā/European and four Asian making up the rest of the graduates. In addition, seven (3.8\%) disclosed their nonheteronormative sexual orientation in the programme and their placement schools and five $(2.7 \%)$ their dyslexia.

\subsection{Compliance with Ethical Standards}

This study involves research with human participants. As such, this study included informed consent. The three student teachers in this paper agreed to have their stories told and volunteered to be included in this study. Ethics approval by the study's university Research Ethics committee was obtained prior to approaching these MTchgLn student teachers for possible inclusion. It should be noted these three student teachers were in the 2015 or 2016 cohorts and at the time of writing in 2017 all three are in New Zealand classrooms as registered teachers.

\section{Life Stories}

As stated, it is illegal to discriminate in New Zealand based on gender, race, ability and sexual orientation. Student teacher experiences, however, indicated that this has not always been their reality. The following three student teachers are examples of how promoting, supporting and facilitating the social justice of student teachers allowed them to challenge a school's, teacher's or educational community's normative attitudes, values and beliefs regarding gender, race, ability and sexual orientation. Witi (all names are self-selected pseudonyms) was a self-disclosed takatāpui (Māori term for those who have same sex attraction) young man who found his first teaching placement in a rugby dominated allboys secondary school troubling. Lisa was a
Pākehā/European young woman who after four years of supporting self-disclosing queer students through a queer support group at university during her undergraduate degree found a co-educational secondary school's reluctance to supporting marginalised youth problematic. Kathy had been labelled for most of her life as the 'dyslexic' girl and chose not to disclose this to her ITE colleagues until after they had formed impressions of who she was based on what she does rather than labels assigned to her. She carried this into her primary school setting so that her school would judge her on her teaching ability not a label. She self-disclosed her dyslexia to her placement class in a teaching moment halfway through her first placement, and encountered dissonance when her mentor teacher then raised concerns over her ability to be a teacher.

\subsection{Witi}

Witi was placed into an all-boys secondary school to support his development as a student teacher. Secondary student teachers in New Zealand are placed in schools that are able to support student teachers in specific subject areas. This school has a strong department in his subjects and these expert teachers would provide him with mentoring in how to bring his subject knowledge into the school system. Witi entered this MTchgLn programme very confident in his subject knowledge. He not only completed his Bachelor's degree but also two Graduate Diplomas in two different languages. He is a fluent speaker of all three languages.

In a class discussion about prior schooling experiences and how student teachers saw the role of the teacher and student, he noted his secondary schooling was not pleasant. He left at the earliest opportunity when he turned 16 . He gained entry into his Bachelor's degree through an alternative university entry pathway. As he studied subjects of personal interest, his confidence in his own abilities increased and his grades reflected his academic ability. He had learned to believe in himself and his own abilities. He applied for entry into this MTchgLn programme with the intention of making a difference. Witi entered this programme with a 
strong sense of mārama (the understanding of one's own identity, language and culture). In his interview, he explained in detail how his students were not going to experience the same negative educational environment he experienced.

As part of the foundation paper of their ITE programme, student teachers compare and contrast the pedagogies of The New Zealand Curriculum (Ministry of Education, 2007) with traditional Māori pedagogies ${ }^{29-30]}$. The intent is to provide the student teachers with explicit opportunities to explore bicultural views and reflect on their own beliefs and values. As a language learner who had spent time overseas in non-English speaking countries, Witi experienced how a different language and culture positively influenced his own personal identity. Now as a student teacher learning to become a language teacher, Witi needed the supported opportunity of an ITE programme to challenge and contribute to both his and his students' whanaungatanga (actively engaging in respectful relationships) and manaakitanga (showing integrity, sincerity and respect). Witi did not need to learn what or how to implement the New Zealand's cultural competencies of ako (to teach and learn), whanaungatanga, tangata whenuatanga (Māori learning as Māori), manaakitanga and wānanga (communicating with Māori to benefit Māori learners) ${ }^{[4]}$. These were concepts he already lived and embraced as a Māori young man. However, returning to an all-boys secondary school at the age of 24 challenged his mārama.

Witi requested a different placement school as a means to avoid returning to an all-boys environment. It took several discussions outside of class between himself and a university mentor to allow him to work through his apprehensions. Then he was willing to accept a tour of his placement school and meet his mentor teacher. This occurred before any of the students returned for the school year. Witi needed to see himself as a teacher not as a bullied 15-year old coming to terms with his sexuality. To support his self-as-teacher role identity development he was given a whakatauki to think about, Ko au ko au, ko koe ko koe, me haere ngatahi (which can be translated as, 'I am me, you are you, but we can go on together'). This whakatauki recognises that while people may be different and hold different ideas, values and beliefs; as a community, they are still able to work together.

Witi needed the confidence to stand in front of a class and feel comfortable being seen as a teacher not an object of ridicule. One of the programme design features of this ITE programme is that student teachers are welcomed as members of the school staff prior to students returning to school. In this regard, they are given more mana (relating to personal status and power) as teaching staff members rather than student teachers. Witi's mentor teacher introduced him to his classes as one of their teachers and then explained how a university mentor would be coming into classes periodically to offer advice and support to both Witi and herself as a means of professional development. This allowed Witi to be himself while being supported both psychologically and professionally in learning how to be the teacher he wanted to be.

Witi completed his placement at this school and then transferred to a co-educational school for his second schooling experience. His time at the all-boys school had more positive moments than negative as he learned that this was his opportunity to develop his own teaching persona. He was not going to be their 'mate' (a term forged in World War 1 that goes deeper than being a friend and is based on shared experiences, mutual respect and unconditional assistance). He was there to learn how to be their teacher, not their 'gay' teacher, not their 'male' teacher or even their 'student' teacher.

\subsection{Lisa}

Like Witi, Lisa was in this ITE programme to be a secondary school teacher. Lisa entered this programme after having spent the past four years while undertaking her bachelor's degree volunteering in a queer support group. She saw student well-being as one of her core responsibilities as a teacher. Lisa was aware that research has identified that one in twelve secondary school students in New Zealand self-identify as queer ${ }^{[31]}$. While Generation Queer (Rainbow Youth 
organisation in New Zealand for 13-18 year olds) was not an option for her friends when she was in secondary school she wanted to support it being available for her students. Several staff members at her placement school questioned her motives and reasons and then raised concerns over her suitability as a secondary teacher.

As part of this ITE programme, student teachers are expected to contribute to the wider school community beyond their classrooms. Questions were raised by the school as to whether advocating for young people to be exposed to these messages was in the best interest of the students. Lisa was first horrified and then incredibly upset. She was not prepared for what she saw as a personal attack and this almost ended her teaching career as a 23-year old.

Like Witi, she saw a whakatauki as a means to help focus her efforts, Ki te kāhore he whakakitanga ka ngaro te iwi (can be translated as, 'Without foresight or vision the people will be lost'). Education is founded on relationships and New Zealand is a small 'town' where everyone knows someone in common. In secondary subjects, this is even more so as secondary subjects have their own nationwide network associations that support their curriculum area.

Lisa felt her career was being terminated as it was just starting but worse was that LGBTQI+ (the inclusive term now commonly used in New Zealand) students were going to continue to be marginalised. Lisa and a university mentor discussed how she could incorporate her sense of student well-being for marginalised youth with what was agreed to be called the 'misunderstanding' of school staff members. Through a series of discussions that included not only the school counsellor but also teachers from other schools, Lisa and a university mentor decided to approach this as an opportunity to promote the Ministry of Education' ${ }^{[32]}$ guide to bully prevention in school, focussing on 'Bystander Intervention' (see pp. 21-23). Bystander intervention allowed Lisa to promote a Ministerial programme that educates students on how they can effectively intervene in bullying. Lisa's approach meant this was a policy aimed at all students and she was able to argue how this would be appropriate as it would encourage students to intervene rather than having their presence be interrupted as support for the behaviour ${ }^{[33]}$. Through this school-wide approach, Lisa was able to promote social relationships amongst all the students to positively support and include each other.

Lisa needed to be prepared to defend and articulate her reasons and motives for wanting to support marginalised youth. She soon discovered that there is a nationwide network associations of support also out there and many other teachers had gone through similar situations. While she saw one of her roles as a teacher as supporting marginalised youth, she learned that there were other teachers, senior teachers, management and principals more than willing to support her in implementing a programme to support marginalised youth.

\subsection{Kathy}

Unlike Lisa and Witi, Kathy studied to teach in primary education. She presented as a confident and capable 28-year old Pākehā/European. In class discussions on how she saw the role of the teacher and student, she became very passionate about equality versus equity. Most of her colleagues answered 'yes' to the question, 'will you treat all your students equally?' She and a few others in the class become vocal around how there was a difference between equality and equity. For most of her colleagues, the New Zealand school system was designed to support them as white, middle-class, Pākehā/European students. At this point, Kathy selfdisclosed her dyslexia and how she experienced school. Her dyslexia meant she had been labelled and marginalised for most of her schooling. She talked about many of her teachers having minimum expectations of what she could do and clearly articulated how she felt about those teachers who had no expectations about her. She had deliberately chosen not to disclose her dyslexia as while they all knew her as Kathy several will now only see her as 'Dyslexic' Kathy. She made the same decision to withhold her self-disclosure for her school placement. In this ITE programme, the student teachers are 
placed in a partner school from the start of the year to see how teachers and schools set up routines and implement teaching programmes. Students are in their school for the first two weeks of the school year and then return for two-days/week before undertaking a sustained placement of four weeks. The student teachers are in schools for this early sustained teaching experience not only to see how the year begins but also to build relationships with both their mentor teacher and students. Over the course of the first term (New Zealand schools generally operation on a four-term school year, each term approximately 10-weeks long), Kathy worked with both her mentor teacher and Year 2 students (7-years old students) to take on more and more of the roll of the teacher. In Term 2, she was in the middle of her four-week sustained teaching experience when she self-disclosed her dyslexia in a lesson. She had been in this class for 37 days without incident and was distraught to find out her mentor teacher had raised concerns with the school's principal over her ability to be a teacher now that she knew Kathy was dyslexic.

Kathy sat in a university mentor's office in tears questioning if she could go back into the classroom and pointed to a whakatauki on the wall, Whaia to ake ngakanui, $i$ te pono, $i$ te marama (which can be translated as, 'Know who you are, be who you are') and simply asked, 'how?' This was taken off the wall, she taped it to the front of her folder and her options were discussed. Kathy saw her role as the teacher as being someone to show her students their potential before their peers and society might teach them otherwise. Kathy knows the importance of early intervention for students with learning barriers $^{[34]}$. She also knows the importance of teachers seeing dyslexia and other learning 'disabilities' as students who need different learning strategies. It was recommended she be the confident, capable and committed Kathy that she was prior this incident and trust the relationships she had built in this school.

While her mentor teacher may have had issues with her dyslexia, her principal did not. Her principal had observed Kathy (and every other student in her school) in class and knew she was on track to completing her placement successfully. Her principal also saw this as an opportunity for staff professional development. The school principal and this ITE programme did not make this an issue between mentor teacher and student teacher. It became a learning opportunity for addressing misconceptions around dyslexia and other labels.

This ITE programme promotes student teachers to be agents of change as first student teachers and then classroom teachers. Teachers are instrumental in addressing students' competence beliefs and sense of value ${ }^{[35]}$. Kathy working with the school's principal co-conducted several sessions of staff professional development where the staff were shown how to work with students to develop personal goals for skill mastery, address the notion of their ideal self, and their perceptions regarding their abilities. Kathy through her own personal experiences explained how personal goals are prominent in leading students to action for reversal of negative beliefs ${ }^{[36]}$. Additionally, Kathy highlighted when students can exercise choice within the appropriate guidance to set goals, they become more engaged and take ownership of their learning. Together Kathy and her principal led the staff through a critical analysis of Urdan and Schoenfelder's ${ }^{[37]}$ article on classroom motivation. They highlighted how when students form their own goals and self-evaluate regarding those goals, attitude and self-efficacy can be improved ${ }^{[37]}$. Teachers needed to understand that as students move in the present towards future images of themselves, their expectations inform the possible self-images which they aspire to ${ }^{[38]}$. Addressing the basic needs of self-worth through competence, and security through relatedness to peers and learning areas are key components of that self-determination process. These professional development sessions culminated in not only the whole school staff but also Kathy establishing positive learning experiences and redressing competency beliefs in learning situations $^{[39]}$.

\section{Final Thoughts}

Life stories are one means of making meaning from 
school situations. It is this interpretation of personal stories interwoven with content understanding that is played out in the classrooms. Teaching is complex and often referred to as a mix of art and science ${ }^{[40-41]}$. Initial teacher education's role is to guide and support student teachers. This involves leading them through both theory and practice. Student teachers come to this study's ITE programme with the dispositions to teach and an interest in teaching. Over the course of this programme they experience modelling and demonstration, document their own growing mastery of skills, increasing sophistication of ideas, and their ability to problematise. For some this journey has additional social justice hurdles to overcome. Witi, Lisa and Kathy are examples of student teachers having social justice issues of gender, race, ability and sexual orientation. New Zealand is not a homogenous society and its school system should reflect this. A whakatauki that is shared with the students early in the programme states, E koekoe te tūi, e ketekete te kākā, e kūkū te kereru ('The tui chatters, the kaka gobbles, the pigeon coos' - a whakatauki used to acknowledge that it takes all kinds to make a strong community). Students then go through several activities that show how they are both similar and unique. As stated, in New Zealand it is illegal to discriminate based on a person's gender, religion, ethnicity, disability, age, politics, ethnicity, sexual orientation. Sometimes, however, the educational community, the teacher or the school needs to be reminded that the normative is not the norm. Just as society is comprised of a range of members, so should its schools as such teachers must strive to learn more about the complexity of their social world and its many interactions.

\section{References}

[1] New Zealand Government. Human Rights Act 1993, 2016a. viewed 23 March 2017, http://www.legislation.govt.nz/act/public/1993/008 2/latest/DLM304475.html

[2] Manning, B. (2013). Census2013: More ethnicities than the world's countries, 2013. viewed 20 August 2017, http://www.nzherald.co.nz/news/article.cfm?c id=1 \&objectid $=11170288$

[3] Ministry of Education. The New Zealand Curriculum. 2007, Learning Media, Wellington, New Zealand.

[4] Ministry of Education. Tātaiako: Cultural competencies for teachers of Māori learners. 2011, Learning Media, Wellington, New Zealand.

[5] New Zealand Government. (2016b). The Education Act 1989. 2016b, viewed 23 March 2017, http://www.legislation.govt.nz/act/public/1989/008

o/latest/whole.html

[6] Pereira, F. Initial teacher education for social justice and teaching work in urban schools: An (im)pertinent reflection. Alberta Journal of Educational Research, 2013, 59: 162-180.

[7] Brown, S., \& Walshaw, M. (Re)conceptualising gender in education: Connecting research, theory, and practice. In A. St George, S. Brown, \& J. O'Neill (Eds.), Facing the big questions in teaching: Purpose, power and learning (2nd ed., pp. 81-87) 2017, Cengage, South Melbourne.

[8] Connell, R. Confronting equality: Gender, knowledge and global change. 2011, Polity Press, Cambridge.

[9] Cochran-Smith, M., Shakman, K., Jong, C., et al. Good and just teaching: The case for social justice in teacher education. American Journal of Education, 2009, 115: 347-377. doi:10.1086/597493

[10] Lahelma, E. Troubling discourses on gender and education. Educational Research, 2014, 56: 171-183. doi.org/10.1080/00131881.2014.898913

[11] Haig, B., Sexton, S. S. Primary students' perceptions of good teachers. set, 2014, 3: 22-28. http://www.nzcer.org.nz/system/files/set2014 302 2.pdf

[12] Watson, A., Kehler, M., Martino, W. The Problem of Boys' Literacy Underachievement: Raising Some Questions. Journal of Adolescent \& Adult Literacy, 2010, 53: 356-361. doi:10.1598/JAAL.53.5.1 [13] Korthagen, F. A. J., Kessels, J., Koster, B., et al. Linking practice and theory: The pedagogy of realistic teacher education. 2008, Routledge, New York.

[14] Cunliffe, A. L. On becoming a critically reflexive practitioner. Journal of Management Education, 2004, 28: 407-426. doi:10.1177/1052562904264440 
[15] Thompson, N., Pascal, J. Developing critically reflective practice. Reflective Practice, 2012, 13: 311325. doi:10.1080/14623943.2012.657795

[16] Timperley, H. Learning to practise: A paper for discussion. 213, Ministry of Education, Wellington, New Zealand.

[17] Schön, D. Educating the reflective practitioner. 1987, Jossey-Bass, San Francisco, CA.

[18] Sexton, S. S. Student teacher learning to think, know, feel and act like a teacher: The impact of a master of teaching and learning programme. Educational Alternatives, 2015, 13: 72-85. https://www.scientificpublications.net/en/article/1000917/.

[19] Sexton, S. S., Williamson-Leadley, S. Promoting reflexive thinking and adaptive expertise through video capturing to challenge postgraduate primary student teachers to think, know, feel and act like a teacher. Science Education International, 2017, 28(2): 132-145.

[20] Connelly, F. M. Clandinin, D. J. Stories of experience and narrative inquiry. Educational Researcher, 1990, 19(5): 2-14. http://journals.sagepub.com/doi/pdf/10.3102/0013 189X019005002

[21] Connelly, F. M. Clandinin, D. J. Telling teaching stories. Teacher Education Quarterly, 1994, 21(1): 145-158.

http://www.jstor.org/stable/pdf/23475539.pdf .

[22] Creswell, J. W. Research design: Qualitative and quantitative approaches. 1994, SAGE, Thousand Oaks, CA.

[23] Carter, K. Preservice teacher's well-remembered events and the acquisition of event-structured knowledge. Journal of Curriculum Studies, 1994, 26: 235-252. doi.org/10.1080/0022027940260301

[24] Dhunpath, R. Life history methodology: 'narradigm' regained. International Journal of Qualitative Studies in Education, 2000, 13: 543-551.

[25] Fenstermacher, G. D. The knower and the known: The nature of knowledge in research on teaching. Review of Research in Education, 1994, 20: 3-56.

[26] Chase, S. E. Narrative inquiry: Multiple lenses, approaches, voices. In N. K. Denzin, Y. S. Lincoln (Eds.), The Sage Handbook of Qualitative Research (3rd ed., pp. 651-675). 2005, SAGE, Thousand Oaks, Ca.

[27] Galbo, J. J. Demetrulias, D. M. Recollections of nonparental significant adults during childhood and adolescence. Youth \& Society, 1996, 27: 403-420. doi/pdf/10.1177/0044118X96027004001

[28] Education Counts. Teaching staff. 2017. viewed 20 September 2017, https://www.educationcounts.govt.nz/statistics/sch ooling/teaching staff

[29] Hemara, W. Māori pedagogies: A view from the literature. 2000, New Zealand Council for Educational Research, Wellington, New Zealand.

[30] Pere, R. R. AKO concepts and learning in the Maori tradition. 1982, Department of Sociology, University of Waikato Monograph. Hamilton.

[31] Le Brun, C., Robinson, E., Warren, H., et al. Nonheterosexual Youth - A profile of their health and wellbeing: Data from Youth 2000, 2004. Viewed 23 march

2017,

https://www.fmhs.auckland.ac.nz/en/faculty/adoles cent-health-research-group/youth2000-nationalyouth-health-survey-series.html

[32] Ministry of Education. Bullying prevention and response: A guide for schools. 2015, Learning Media, Wellington, New Zealand.

[33] Denny, S., Peterson, E., Stuart, J., et al. Bystander Intervention, Bullying, and Victimization: A Multilevel Analysis of New Zealand High Schools. Journal of School Violence, 2015, 14: 245-272. doi.org/10.1080/15388220.2014.910470

[34] Ferrer, E., Shaywitz, B. A., Holahan, J. M., et al. Achievement Gap in Reading Is Present as Early as First Grade and Persists through Adolescence. The Journal of Pediatrics, 2015, 167: 1121-1125. doi.org/10.1016/j.jpeds.2015.07.045

[35] Hattie, J. Visible learning for teachers maximizing impact on learning. 2012, Taylor and Francis, New York, NY.

[36] Wigfield, A., Eccles, J. Development of competence beliefs, expectancies for success, and achievement values from childhood to adolescence. In G. Phye (Ed.), Development of achievement motivation (pp. 91-120). 2002, Academic Press, San Diego, CA.

[37] Urdan, T., Schoenfelder, E. Classroom effects on 
student motivation: Goal structures, social relationships, and competence beliefs. Journal of School Psychology, 2006, 44: 331-349. doi:10.1016/j.jsp.2006.04.003

[38] Carver, C., Scheier, M. On the structure of behavioral self-regulation. In $\mathrm{M}$. Boerkaerts, P. Pintrich, \& M. Zeidner (Eds.), Handbook of selfregulation (Vol. 13, pp. 41-48). 2000, Academic Press, San Diego, CA.

[39] Zimmerman, B. Attaining self regulation: A social cognitive perspective. In M. Boekaerts, P. Pintrich, \& [40] M. Zeidner (Eds.), Handbook of self-regulation
(Vol.13, pp. 695-716). 2000, Academic Press, San Diego, CA.

[41] Ausubel, D. P. The acquisition and retention of knowledge: A cognitive view. 2000, SpringerScience+Business Media B.V., Dordrecht, The Netherlands.

[42] Fraser, D. The work and artistry of teaching. In D. Fraser \& M. Hill (Eds.), The professional practice of teaching in New Zealand (5th ed., pp. 56-78). 2016, Cengage, South Melbourne. 